This article was downloaded by: [Richardson, John E]

On: 23 September 2009

Access details: Access Details: [subscription number 915188718]

Publisher Routledge

Informa Ltd Registered in England and Wales Registered Number: 1072954 Registered office: Mortimer House, 37-41 Mortimer Street, London W1T 3JH, UK

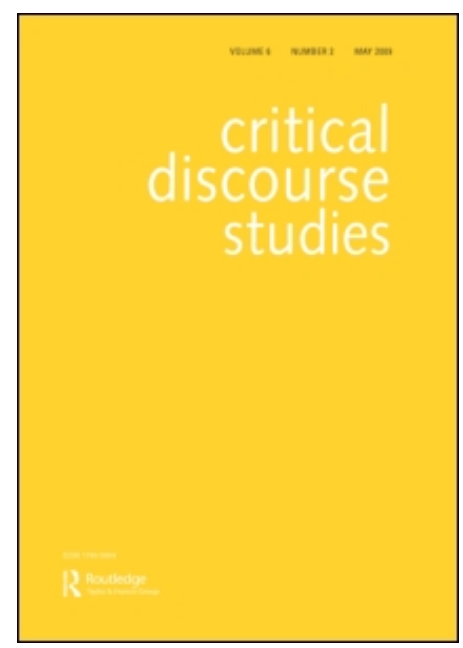

\title{
Critical Discourse Studies
}

Publication details, including instructions for authors and subscription information:

http://www.informaworld.com/smpp/title content=t713695016

\section{Recontextualising fascist ideologies of the past: right-wing discourses on employment and nativism in Austria and the United Kingdom}

John E. Richardson a; Ruth Wodak ${ }^{\text {b }}$

a Department of Social Sciences, Loughborough University, Loughborough, UK ${ }^{b}$ Department of Linguistics and English Language, Lancaster University, Lancaster, UK

Online Publication Date: 01 November 2009

To cite this Article Richardson, John E. and Wodak, Ruth(2009)'Recontextualising fascist ideologies of the past: right-wing discourses on employment and nativism in Austria and the United Kingdom',Critical Discourse Studies,6:4,251 — 267

To link to this Article: DOI: $10.1080 / 17405900903180996$

URL: http://dx.doi.org/10.1080/17405900903180996

\section{PLEASE SCROLL DOWN FOR ARTICLE}

Full terms and conditions of use: http://www.informaworld.com/terms-and-conditions-of-access.pdf

This article may be used for research, teaching and private study purposes. Any substantial or systematic reproduction, re-distribution, re-selling, loan or sub-licensing, systematic supply or distribution in any form to anyone is expressly forbidden.

The publisher does not give any warranty express or implied or make any representation that the contents will be complete or accurate or up to date. The accuracy of any instructions, formulae and drug doses should be independently verified with primary sources. The publisher shall not be liable for any loss, actions, claims, proceedings, demand or costs or damages whatsoever or howsoever caused arising directly or indirectly in connection with or arising out of the use of this material. 


\title{
Recontextualising fascist ideologies of the past: right-wing discourses on employment and nativism in Austria and the United Kingdom
}

\author{
John E. Richardson ${ }^{\mathrm{a} *}$ and Ruth Wodak ${ }^{\mathrm{b}}$ \\ ${ }^{a}$ Department of Social Sciences, Loughborough University, Loughborough, UK; ${ }^{b}$ Department \\ of Linguistics and English Language, Lancaster University, Lancaster, UK \\ In this article, we trace the histories of discourses supporting 'jobs for natives' in the UK and \\ Austria using the discourse-historical approach (DHA) to critical discourse studies. DHA uses \\ four 'levels of context' as heuristic devices in critical analysis. In this article, we focus our \\ attention predominantly on the broadest of these, largely eschewing the text internal \\ analysis typical of CDA, in favour of a wider contextual sweep. In this way, we \\ deconstruct and trace the conceptual history of British and Austrian slogans of the extreme \\ right related to issues of un/employment. We argue that slogans such as 'British Jobs for \\ British workers' and 'Austria First' have been recontextualised into current political \\ rhetoric while carrying historical context-dependent connotations, stemming from pre- \\ World War II colonialism and antisemitism. Hence, we further claim that - although such \\ rhetoric is currently widespread across EU member states - the ideologies and traditions \\ drawn upon are distinct and create specific subtexts to be exploited for political ends; this \\ is part of the discursive strategy of 'calculated ambivalence' employed in such rhetoric.
}

Keywords: critical discourse analysis; discourse-historical approach; far-right; fascism; nativist jobs discourse; semantic history

\section{Contextualising contemporary discourse}

On 10 September 2007, Gordon Brown gave his first speech as Prime Minister to the Trades Union Congress. In this speech, described as a bid to 'outflank [Conservative Leader] David Cameron over immigration', ${ }^{1}$ he pledged to guarantee a 'British job to every British worker'. This would be achieved through, amongst other measures, requiring migrant workers 'to learn English - a requirement we are prepared to extend to lower skilled workers as well'. ${ }^{2}$ Two weeks later, on 24 September 2007, Brown took his message to the Labour Party Conference and a much wider national audience. The press had been briefed on what he would say: British patriotism and British workers would form central planks to his conference address. In the days that followed, journalists and political commentators focused their, and our, attentions on a short passage and on one phrase in particular, a little over half way into the speech:

As we set out on the next stage of our journey this is our vision: Britain leading the global economy

[...] a world leader in the creative industries; and yes - modern manufacturing too - drawing on the talents of all to create British jobs for British workers.

The significance of this populist 'vision' of the British economy was not lost on most people that heard it: we must protect 'Our jobs' from immigrant workers. By 2007, immigration had been a concern for New Labour for some considerable time, especially since the EU enlargement of 2004. From around 2002, the Labour Party assumed that 'fear of migration, and asylum seekers in particular, was responsible for an increase in support for the BNP [British National

${ }^{*}$ Corresponding author. Email: j.e.richardson@lboro.ac.uk 
Party] and that therefore the government had to be seen to be addressing these concerns' (Schuster \& Solomos, 2004, p. 278). A week before the 2002 Labour Party Conference, Philip Gould - Tony Blair's advisor and a senior architect in the New Labour project wrote an article for the magazine Progressive Politics, edited by Peter Mandelson MP, in which he suggested: 'It is not the comfortable middle classes who have most to fear from migration, but those at the cutting edge of vulnerability. ${ }^{3}$ They must be made to feel that their fears are being addressed, he argued, by the Labour government getting 'tough' on immigration. Picking up on the political mood, the Conservative Party also adopted racial populism as a central campaign strategy, with one of their five key election policies in the 2005 General Election centred on reducing immigration (see Wodak, 2008, pp. 70-71, for details). However, if this repeated tightening of immigration policy was, indeed, intended to undermine the political and electoral power of the BNP, Britain's largest far-right political party, it was not effective.

A racist anti-immigrant policy, based on nativist ideology, remains openly at the heart of the BNP: the party's Constitution states they are 'committed to stemming and reversing the tide of non-white immigration and to restoring, by legal changes, negotiation and consent, the overwhelmingly white make-up of the British population that existed in Britain prior to 1948 '. However, the Party conceals this core racist ideology, acknowledging its aim for a white Britain only in documents rarely read by non-members. In its more widely disseminated election materials, the party emphasises 'Britain', cultural identity and a range of political commonplaces that most democratically minded Britons would be hard-pressed to object to (see Richardson, 2008; Richardson \& Wodak, in press). Nick Griffin, the current leader of the party, is also on the record arguing explicitly for this Janus-faced propaganda technique - which corresponds to the discursive strategy of 'calculated ambivalence' (Engel \& Wodak, 2009). In an article published in the magazine Patriot soon after his first trial for incitement for racial hatred, Griffin outlined to BNP activists his plans for the 'modernisation' of the party. He wrote:

As long as our own cadres understand the full implications of our struggle, then there is no need for us to do anything to give the public cause for concern [...] we must at all times present them with an image of moderate reasonableness. [...] Of course, we must teach the truth to the hardcore, for, like you, I do not intend this movement to lose its way. But when it comes to influencing the public, forget about racial differences, genetics, Zionism, historical revisionism [i.e. Holocaust denial] and so on - all ordinary people want to know is what we can do for them that the other parties can't or won't. (cited in Brown, 2007)

The importance of this extract - acknowledging that the BNP adopts a 'moderate' public face to hide a racist and antisemitic ideological core - cannot be over-emphasised. Employing this campaign tactic, coupled with factors such as inter alia the financial crisis, high unemployment and general dissatisfaction with the mainstream parties, the BNP are currently achieving a level of electoral success that is unparalleled in the history of the British far-right (see John, Margetts, Rowland \& Weir, 2006). This recent electoral success also relates, directly, to the prominence of prejudiced ideas and arguments about racial and ethnic 'others' in mainstream political debates. As Cohen argues, 'in the UK there exists an historical and inextricable relationship between immigration controls and both fascistic thought and fascistic agitation' (2006a, p. 7). While 'the present government rarely [uses] any explicitly racist metaphor to justify its constant tightening of immigration controls' (p.13), its policy decisions nevertheless still give succour to fascist and far-right parties.

Predictably, in the months following Brown's speech, the BNP laid claim to the phrase 'British Jobs for British Workers', arguing that the slogan had been "'borrowed" from the BNP'. 5 The BNP has emphasised this argumentative line ever since, putting the slogan at the centre of their election campaign for the European Parliament, on 4 June 2009 (Figure 1). We return to this leaflet at the end of this article. 

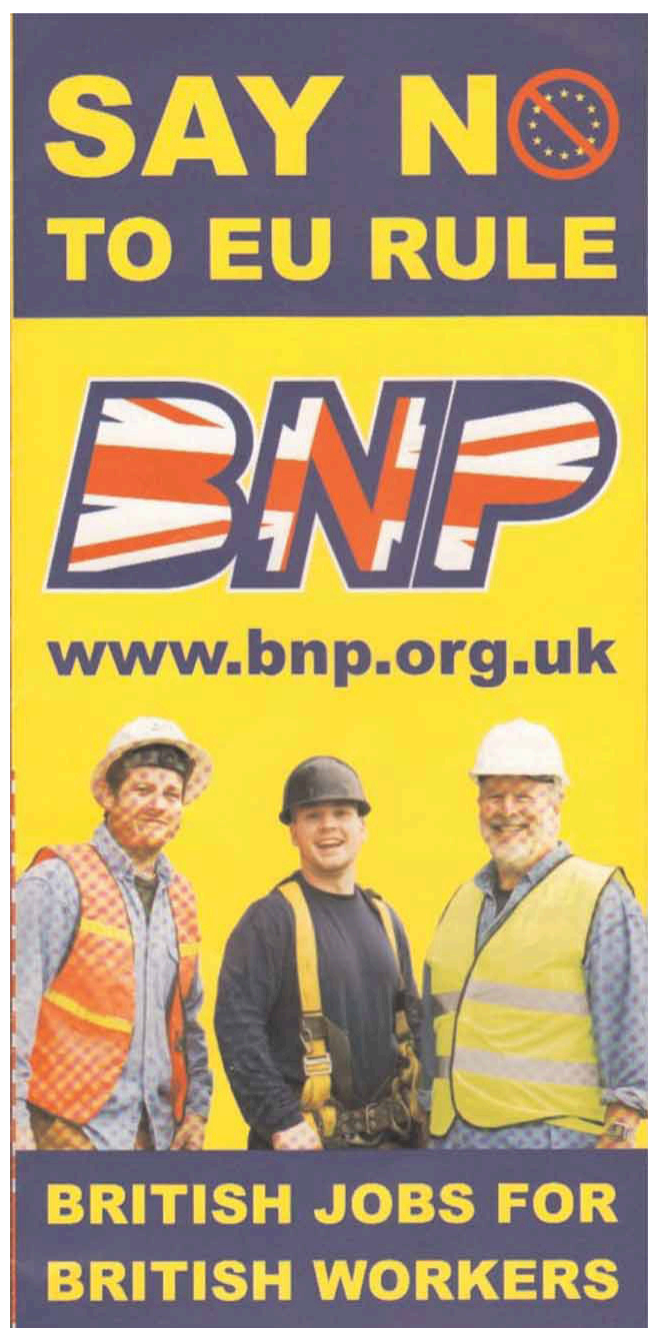

Figure 1. BNP, 'British Jobs for British Workers'.

However, this nativist jobs discourse is neither a new phenomenon, nor is it limited to the UK. In Austria, the most politically significant advocates of nativism are the Freedom Party of Austria (FPÖ) and The Union for Austria's Future (BZÖ). The FPÖ dates back to post-war Austria and the political set-up created by the Allies (the USA, the UK, France and the Soviet Union, enabling them to keep control over Austria until the 'Staatsvertrag' of 1955). When, in June 2004, the FPÖ suffered a huge defeat in elections to the European Parliament, Jörg Haider created a new party, the BZÖ, in the spring of 2005. The FPÖ continued, headed by H.-C. Strache. The electoral result of 2006 proved to be far too modest for the FPÖ and BZÖ to become coalition partners in a government, and the FPÖ and the BZÖ returned to their oppositional role(s). ${ }^{6}$ Haider died on 10 October 2008, in a car accident caused by speeding whilst drunk, and since then the FPÖ has gained almost $27 \%$ in the opinion polls (and $12.7 \%$ in the EU elections on 7 June 2009, thus doubling their results from last time), while the BZÖ remains the strongest party in Carinthia with over $45 \%$ in recent regional elections. Both parties employ blatant Islamophobic rhetoric while insinuating antisemitic stereotypes (Richardson \& Wodak, in press). During the elections for the European Parliament, anti-EU sentiments were combined with Islamophobic and antisemitic images, slogans, and metaphors, such as 'Abendland in Christenhand' (The West in the hands of Christianity) or 'Veto gegen Türkei und Israel in die EU' (Veto against the accession of Turkey and Israel into the EU) - an obvious fallacy as Israel is not attempting to join the EU, adding an ambivalent antisemitic 
meaning to the campaign. 'Austria First' (a slogan drawing on the 'Austria First' petition from 1992/1993; see below) also relates to employment policies: the FPÖ campaign materials for the Workers Chamber elections spring 2009 indicate:

Work is homeland [Heimat]. We want to remind the government [...] that it is a major aim of the social state to provide the state-population - i.e. the originally 'rooted' population - enough jobs [...] so that the Austrian families are enabled to keep their standard of living. ${ }^{7}$

The high-value term of 'Heimat' (fatherland/home) triggers many emotional connotations and addresses more evocative and solidarity-promoting meanings than 'state' or 'nation'. It is therefore mainly used by German nationalists who endorse an ethically defined notion alluding to a kind of greater 'German nation' (Reisigl \& Wodak, 2000, p. 288).

The Party Programme of the BZÖ (2009) also contains paragraphs related to 'Heimat', employment and environment, labelled as 'Lebensraum', a term central to Nazi rhetoric. Here, we only quote some extracts of the paragraph dedicated to the latter (Figure 2).

In this quote we encounter a good example of interdiscursivity: the discourse about health and organic food is linked to EU-sceptic rhetoric and the danger of losing jobs; this time, the programme implies that job loss is triggered by new technology and by EU lobbies. A conspiracy against 'our farmers' is alluded to, a typical discursive strategy which serves constructing scape-goats and/or vague conspiracies. Indeed, these discursive strategies relate to widely spread antisemitic rhetoric as has been extensively illustrated in previous research on Austrian right-wing rhetoric (Wodak et al., 1990; Pelinka \& Wodak, 2002) and the UK (Billig, 1978; Eatwell, 1991); we return to the loaded term 'Lebensraum' below.

In this article, we trace the histories of nativist jobs discourse in the UK and Austria in order to contextualise and more fully elucidate its use in contemporary political debates. The next section presents a synoptic account of the discourse-historical approach to discourse studies, developed by Ruth Wodak and colleagues (Wodak et al., 1990; Reisigl \& Wodak, 2001, 2009; Wodak, 2001). As Wodak \& Meyer (2009, p. 19) argue, frequently political media utilise myths "to provide new "sanitized" narratives which cover up ruptures, war crimes and conflicts which have occurred in the past'. Just as serious, the past may not be merely sanitised in political discourse but ignored completely - literally, consigning it to the history books. In order to make the history - and hence the meaning - of nativist jobs discourse more knowable, we unearth past instances in which such prejudicial arguments were invoked, examine their (ideological) assumptions, and their (frequently coded) argumentative and referential strategies.

\begin{abstract}
$\rightarrow$ Die orange Position zum Thema "Lebensraum"
Nur eine saubere Umwelt ist lebenswert. Dies bedingt den Schutz der Umwelt und die Pflege der Kulturräume. Wir sind für selbstverantwortliches Handeln statt verordnetem Umweltschutz bei konsequenter Anwendung des Verursacherprinzips. Kleingewerbe und Landwirtschaft sind für die ländlichen Regionen überlebensnotwendig und daher zu unterstützen und zu fördern. Wir sind gegen die Agrarlobby der Europäischen Union sowie deren Forcierung der Gentechnik. Unser Bestreben ist eine Renationalisierung der Landwirtschaft. Das sichert das Überleben unserer Bauern und fördert die Herstellung von gesunden Lebensmitteln.
\end{abstract}

\title{
Orange Ziele \& Antworten
}

Umweltstandards für Industrie und Wirtschaft - Förderung der biologischen und ökologischen Landwirtschaft - Stärkung des ländlichen Raumes - Förderung erneuerbarer Energie - Atom- und gentechnikfreies Europa - Renationalisierung der Landwirtschaft - Sicherung des Arbeitsplatzes Bauernhof- Kein subventionierter Transit.

Figure 2. 'The orange position on the theme of "Lebensraum". 8 
Finally, we return to the political leaflets and quotes discussed above, focusing on their contextrelated meanings and the similarities and differences between the texts of the two parties. We claim that, in spite of the salient historical differences, nativist ideologies across the EU and Europe are converging; it remains to be investigated if they currently carry similar meanings or if specific pasts impinge on the present, and in which specific ways.

\section{The discourse-historical approach}

The DHA provides a vehicle for looking at latent power dynamics and the range of potentials of agents, because it integrates and triangulates knowledge about historical sources and the background of the social and political fields within which discursive events are embedded. Four 'levels of context' are used as heuristics to locate discursive practices, strategies and texts in a specific socio-political context. The methodology analyses in a recursive manner: (a) the immediate, language or text internal co-text (e.g. in the context of this paper, the slogans of the BNP and FPÖ); (b) the intertextual and interdiscursive relationship between utterances, texts, genres and discourses (e.g. the history and intertextual references of terms and concepts used); (c) the extra-linguistic social/sociological variables and institutional frames of a specific 'context of situation' (e.g. specific election campaigns); and (d) the broader socio-political and historical contexts, within which the discursive practices are embedded (e.g. the history of the respective political parties). These context layers enable researchers to deconstruct the meanings related to contextual levels and frames that impinge on the unique realised texts and utterances. Moreover, the DHA distinguishes between three dimensions which constitute textual meanings and structures: the topics which are spoken/written about (e.g. immigration); the discursive strategies employed that contain '[P]resupposition[s] [that] can be seen as a way of strategically “packaging" information' (Chilton, 2004, p. 64); and the linguistic means that are drawn upon to realise both topics and strategies.

The DHA thus contextualises utterances in relation to other discourses, social and institutional reference points, as well as socio-political and historical contexts and events. Within this it seeks to identify inter alia the effect of particular discursive strategies that serve to present the arguments of an individual or a group either positively or negatively (see Reisigl \& Wodak, 2009). In terms of the argumentation form employed, content-related warrants ('conclusion rules') are used to connect the argument(s) with the conclusion ('the claim') used in particular utterances, and hence provide justification of the latter. Moreover, we combine 'semantic history' with the DHA. Most notably associated with the historian Reinhart Koselleck, 'semantic history' or Begriffsgeschichte (BG; 'the history of concepts') can be characterised as linguistically oriented social history (Koselleck, 1992). BG focuses on the contextually situated historical study of 'key concepts' or Grundbegriffe (in our case, some of which have become topoi ${ }^{9}$ ), which are seen to possess a mobilising force in critical moments in history. In tracing the histories of the nativist job ideologies, we combine BG with the DHA where intertextual and interdiscursive relationships to other genres and discourses, both synchronically and diachronically, can be made explicit which often manifest latent belief systems, ideologies and power relations as well as structures of dominance.

\section{Histories of nativist jobs discourse}

In political discourse of the twentieth century, discriminating against immigrant workers has oscillated 'between social racism and economic racism - the social racists want neither labour nor the presence of the alien, the economic racists want the labour and tolerate the presence' (Cohen, 2006b, p. 96). Legal discourse and mainstream politics have tended to favour 
economic arguments to justify racist anti-immigrant policies, even when the political goals were more akin to the wholesale restriction of 'the alien' on racial or ethnic grounds. In discussing these histories, two referential questions are apposite: who were 'the British' or 'the Austrians' taken to be? And who were the 'aliens'? That is, who were included as 'Us' and who were excluded in nativist jobs discourse?

Looking first at the UK, the 1905 Aliens Act was designed to restrict the entry into the UK of Jewish emigrants and refugees from Russian, Latvian and Ukrainian pogroms. It was underwritten by, and therefore implicitly justified this racism with recourse to, an economically based discourse in support of native employment. However the Act 'did not exclude Jews by name no more than modern legislation refers to black people. Instead it purported to restrict "undesirable immigrants"'(Cohen, 2006a, p. 58), wherein 'an immigrant shall be considered an undesirable immigrant if he cannot show that has in his possession or is in a position to obtain the means of decently supporting himself and his dependants' (1905 Aliens Act, section 1 para 3a). In addition, the Act defined an 'immigrant' as 'an alien steerage passenger who is to be landed in the United Kingdom' (section 8 para 1) - that is, a passenger travelling third class. The law therefore directly targeted Jewish refugees too impoverished to travel any other class.

In parallel, and in seeming contradiction to the demand that immigrants prove they could decently support themselves and their families, 'was the recurring assumption that Jews should be kept out unless they could prove they were not displacing "English" labour' (Cohen, 2006a, p. 60). Cohen cites the example of Liebel Zaruk, a tailor, who was refused admission by the Board of Immigration despite producing a letter from a relative confirming that he had gainful employment. 'The Chairman of the Board ignored this and asked "Would the coming of this man displace another worker?"'(ibid.). Thus, Jewish refugees were barred entry to the UK when they could not prove they had obtained employment, and they were frequently excluded when they could prove this.

The British State and its representatives are not the only bodies committed to tighter controls on the entry and employment of migrant labour. In its 1892 Annual Report, the Manchester Trades Council argued for stopping the immigration of 'foreign workmen' using economic justification behind 'a half-concealed anti-Semitism' (Cohen, 2006a, p. 72):

The question was considered by the Council to be of great importance, the labour of our countrymen being undersold by foreigners coming to this country ready to accept any wages that may be offered to them and willing to work any number of hours [...] the foreign workman is induced to come over here by some of his wealthy countrymen or co-religionists so that he may be worked and sweated to the detriment of his own people. (Ibid. emphasis added)

Following the First World War, fascist parties took up the fight for "restrictions on "alien" immigration, by which they usually meant Jewish immigration' (Lunn, 1989, p. 150), with the British Fascists using the slogan 'Britain for the British' in their 1925 Manifesto. This series of codes, euphemisms and shorthands - in which Jews are identified as aliens and, as such, not British/ Austrian - continues to be invoked in far-right discourse, frequently coded further by referring to Jews as 'International Finance'. However, in contemporary discourse, such antisemitism has been largely superseded by anti-Muslim and anti-Black prejudice, expressed in an identical argumentative manoeuvre: minority communities are identified as aliens and, as such, not British/Austrian. The 'true Brit' or 'der echte Österreicher', is white. ${ }^{10}$ Examples of this coded argumentation are legion, so we will only reproduce a very small sample here.

Our first extract is taken from a leaflet produced and distributed by the National Party:

\section{The National Party puts Britain First!}

- BRITAIN FOR THE BRITISH

We must preserve our distinct national and racial character with its unique talents and abilities, because this is our greatest asset for the future. We must stop all further immigration of non-British 
stock, and organise the humane repatriation or resettlement abroad of all Coloured Immigrants, their dependants and descendants.

- BRITISH JOBS FOR BRITISH WORKERS

We must protect the jobs of British workers by halting the importation of foreign manufactured goods which we can produce ourselves. We must get Britain out of the Common Market, and rebuild our links with the White Commonwealth countries which have complementary economies to our own.

In the extract above, the National Party - a more openly racist splinter party from the then more populist National Front - repeatedly uses 'Britain' and 'British' as the terms of reference, but it is clear that they do not mean British in the legal or civic sense: 'British' refers to a race (cf. 'racial character') or a 'stock', whose 'unique talents' are threatened by the immigration of 'non-British', 'Coloured Immigrants'. The descendants of 'Coloured Immigrants' are also positioned as 'non-British' - and consequently threatened with 'humane repatriation' - so underscoring the argument that national identity is a matter of biological heredity, and only nonColoured (i.e. white) people are/can be British. From this, the actual meaning of their slogan 'British jobs for British workers' is clear: jobs for (only) white people.

The slogan 'Britain for the British' was also discussed by John Tyndall, the then-leader of the National Front, in a National Front Policy Committee pamphlet detailing their economic policy:

Bob Blatchford [...] who used the slogan 'Britain for the British', would be hard put, were he alive today, to believe that the Labour Party is utterly dedicated to transforming Britain into a multi-racial society and to that end has allowed the biggest alien invasion of these shores that has ever been known. Likewise would the old pioneers be appalled at the fact that Labour is now merely the pawn of huge financial interests. (Tyndall, 1977, p. 13) ${ }^{11}$

Here, again, the full meaning of the tautology 'Britain for the British' is revealed by examining what it is compared to and what it is threatened by: Britain is being transformed (seemingly against its will) 'into a multi-racial society' by an 'alien invasion'. Thus, the (black) people who transform Britain from a mono-racial (white) society to a multi-racial one are cast as 'aliens' and, as such, non-British. The final line implicitly indexes an antisemitic conspiracy theory as an explanation for this 'invasion': 'they' are here because the Labour party are controlled by 'huge financial interests', a code word in fascist discourse for 'the Jews'. This antisemitic insinuation is cemented through Tyndall's complimentary reference to Blatchford at the start of the extract. In his most (in)famous book, Merrie England, Blatchford repeated rails against the apparent perfidious influence of 'the Jew' - a group of people who, in typically contradictory fashion, were simultaneously wealthy usurers capable of lending the Government 'a million at 3\%' in order to claim interest on the debt 'forever', and the 'poor unshorn and unsavoury children of the Ghetto' whose 'presence is often a menace and an injury to the English working classes' (cited by Silberner, 1952, pp. 40-41). The implications of citing Blatchford, coupled with the reference to 'huge financial interests', would act as a 'dog whistle' to antisemitic initiates reading this pamphlet.

In Austria, lacking both a Commonwealth of (ex-)colonies and post-World War II immigration from these countries, nativist jobs ideology and related discourse developed differently, having their roots in rising nationalism in the nineteenth century, in antisemitism and national-socialism after World War I and the end of the Habsburg Monarchy, as well as in Austro-fascism after 1933. Thus, we encounter many instances of antisemitic nativist rhetoric in Austria's First Republic, inter alia from the Christian-Social Party, the forerunner of the ÖVP: for example, election posters addressing 'Deutsche Christen' ('German Christians') with the explicit and direct speech-act of appeal 'Rettet Österreich' ('Rescue Austria'), 1920 (Figure 3), which depict 'the dangerous Jew' as a vicious snake strangling the Austrian Eagle in the Austrian coat of arms while employing traditional antisemitic visual features and tropes 


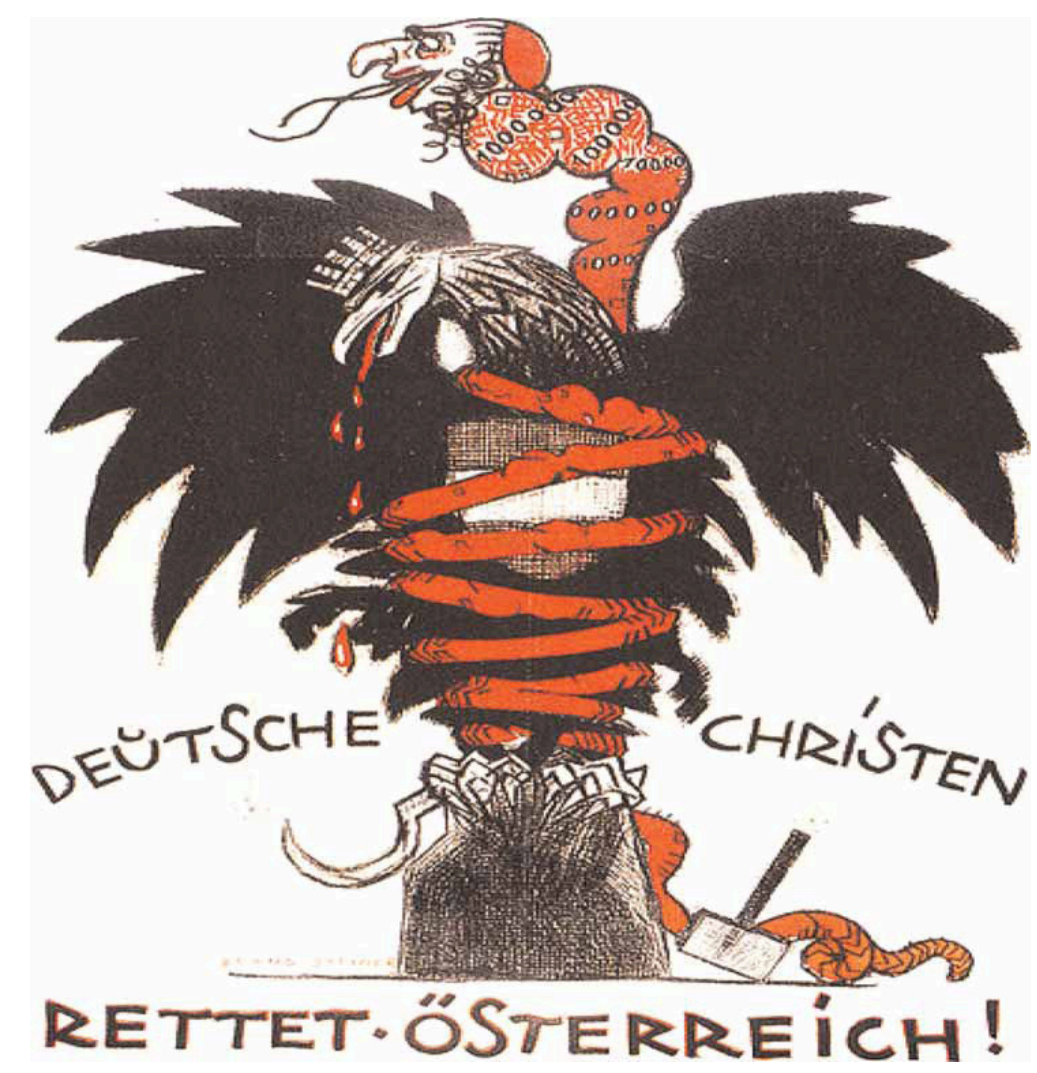

Figure 3. German Christians - Rescue Austria (1920).

(topos of threat, employed as part of visual argumentation; see Richardson \& Wodak, in press, for details of such argumentative-visual rhetoric in the genre of election posters). ${ }^{12}$

After 1945, insinuations and presuppositions frequently infer, and draw on, pre-World War II and Nazi measures against Austrian Jews, Roma and other people regarded as inferior due to Nazi ideology (Krzyżanowski \& Wodak, 2008, p. 33ff). Images such as that reproduced below form part of collective memory of the exclusion and extermination of German and Austrian Jews and of the violence enacted against Austrian- or German-Jewish shop owners (Figure 4).

The Association of Independents 'VdU' (the forerunner of the FPÖ) was formed in 1949 by incorporating a vast array of political movements comprising 'old Nazis, German nationalists and a fair number of liberals' (Schiedel \& Neugebauer, 2002, p. 16) and, in the 1949 parliamentary elections, they won $12 \%$ of the national vote. The main argument the VdU employed rested 'above all on the reversal of the perpetrator-victim dichotomy: the real victims were not those persecuted by the Nazi regime, but those who had profited by acquiring Jewish property ('Aryanizers') and former members of the NSDAP' (ibid.). Hence, 'when the VdU spoke about fascism, it mentioned neither National Socialism nor the Holocaust, at best indicating the "positive aspects" of German fascism, such as full employment and economic growth' (ibid.), thereby allowing for a revival of Austrian 'pro-fascist' sentiment on a national scale and making such sentiment a significant element of the country's political agenda to date. The FPÖ was established in 1955/1956, being 'funded as a German nationalist party of the far right, in which former, seriously incriminated National Socialists took the leading functions' (Schiedel \& Neugebauer, 2002, p. 16). ${ }^{14}$ On 14 September 1986, the FPÖ national convention witnessed a coup - against the more liberal stream of the FPÖ - led by Jörg Haider, who became the new federal chairman of the party (Gärtner, 2002). Haider's arrival as FPÖ chairman marked the shift of the majority of the FPÖ to radical nationalist views. With the aid of antisemitic, 


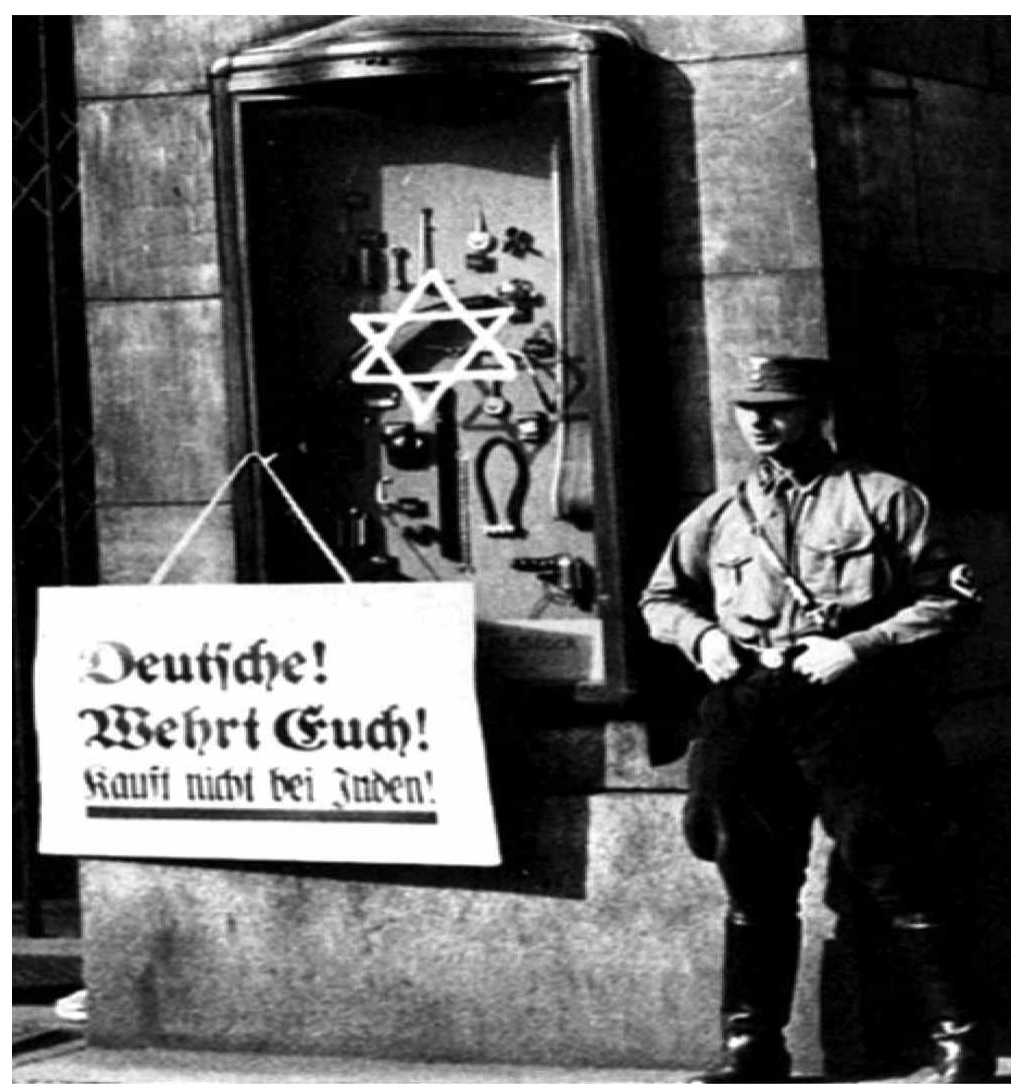

Figure 4. Germans, defend yourselves! Don't buy from Jews! ${ }^{13}$

anti-foreigner and Nazi-sympathising slogans, Haider - a very skilful demagogue who, despite his youth, pledged allegiance to the Nazi traditions of his family - led the FPÖ to successful elections at both the national and regional levels. Revisionist (Nazi) ideology became explicit, for example, when Haider stated that ' $[\mathrm{I}] \mathrm{n}$ the Third Reich, they had respectable (ordentliche) employment policies to keep people occupied, not even the government in Vienna can do that' in a heated debate in the Carinthian Regional Chamber (13 June 1991). Haider had to step down as regional governor after this remark, which clearly implied that forced labour in Concentration Camps could be perceived as 'respectable employment policies' but was reinstated in this function in the same year, after having won the regional election (see Wodak, 2003, pp. 134-136; Krzyżanowski \& Wodak, 2008, pp. 35-41).

The most significant recent shift in anti-immigrant rhetoric started immediately after the fall of the 'Iron Curtain' in 1989. Extremist right-wing populist parties started campaigning against immigration from the former Eastern Communist countries, and the FPÖ gained significant influence by becoming the principal mediator of anti-foreigner sentiment. Mainstream parties joined this campaign, believing they would be able to keep voters this way - a belief which soon turned out to be wrong (Wodak \& van Dijk, 2000), a political strategy similar to the one described above for the British case. Voters preferred to vote for the extremist right-wingers instead of staying with parties which obviously played 'the race card' due to pragmatic-populist considerations. For example, Matouschek, Wodak, \& Januschek (1995, p. 25ff) document the shift in public opinion, triggered by utterances such as 'The Boat is full' (Peter Marizzi, SPÖ), which alluded to a slogan used by the Swiss government in 1938 to 'protect' Switzerland from Jewish refugees fleeing Nazi Germany and Austria and drew on the topos of burden; or the infamous utterance by then regional governor of Upper Austria, Josef Ratzenböck (ÖVP), 'We are dealing with people whose origins one can clearly tell just by looking; and thus, losses for 
tourism are to be expected' (9 March 1990; Der Standard, 10 March 1990). Because of the party's position on immigration, the FPÖ capitalised on this anti-immigrant rhetoric, increasing its share of the vote in 1994 to $22.5 \%$. In the parliamentary elections held on 3 October 1999, the FPÖ received $26.9 \%$ of the national vote and entered the federal government on 4 February 2000. It must be emphasised at this point that, in this way, a radical-right party that had frequently expressed coded praise for Nazi fascism had come to power in an EU member state for the first time ever.

In the following we first briefly list some of the anti-immigration legislation in recent Austrian politics ${ }^{15}$ and simultaneously focus on the recontextualisation of nativist rhetoric. The 1992 Residence Act (Aufenthaltsgesetz) was the first immigration regulating law passed in Austria in the 1990s. It was aimed at the 'unwanted groups of migrants' (e.g. migrants from outside the EU) whose numbers in Austria grew after 1989 (Bauböck, 2003, p. 14). This law fits with the wider European context and was passed on the initiative of the SPÖ with support of the ÖVP. According to Bauböck (2003, pp. 14-15), amongst the most far-reaching provisions of this law were inter alia 'the introduction of an annual quota for newly arriving migrants, which, until the amendment of the Act in April 1995, included [migrant] children born in Austria' and the introduction of the rule that 'applications for residence can only be made from abroad' (ibid.; see also Krzyżanowski \& Wodak, 2008, p. 41ff). After the introduction of this law, 'a substantial halt to new arrivals of migrants took place while the number of family reunions also went down' (ibid.). The salient legislative measure that still regulates migration in Austria is the so-called 'Foreigners Act' (Fremdengesetz). This regulates foreigners' entry into and residence in Austria, while explicitly defined periods of entry and short stay range from three to six months according to various forms of permits, which focus primarily on so-called 'key workers' (Schlüsselkräfte), their spouses and unmarried children, and family members of non-EU member state nationals who settled in Austria before 1 January 1998. After Austria's accession to the EU in 1995, the citizens of EU member states enjoy 'exemption from visa requirements' (Sichtvermerksfreiheit) along with the 'right of domicile' (Niederlassungsfreiheit), which together allow them to enter and remain in Austria without any further permits (although they have to register with the police) except for citizens from the 2004 and 2007 enlargement countries, who need to wait until 2011 to obtain the same rights as all other EU citizens.

The 'Austria First' petition of October 1992 received 417,278 signatures (7\% of eligible voters) and secured the FPÖ a significant rise in its electoral support. The title of the petition ('Österreich Zuerst') draws analogously on the slogan of the extremist right-wing German party DVU (Deutsche Volksunion, founded by Gerhard Frey in 1971), 'Deutschland Zuerst', used since 1987 in their xenophobic and chauvinistic programme. ${ }^{16}$ Ever since, 'Österreich Zuerst' has become a topos in extremist right-wing rhetoric demarcating xenophobic ideologies, frequently coupled with Christian values (Reisigl \& Wodak, 2001, p. 194ff). ${ }^{17}$ We only quote the first paragraph here (see Reisigl \& Wodak, 2000, pp. 287-288; Wodak, 2001, for the entire text and its in-depth analysis):

Subtitle: through secure creation of legal measures that permanently protect the right to a fatherland (Heimat) for all Austrian citizens and, from this standpoint, ensure a restrained immigration policy in Austria

1.The adoption of a national law to anchor the national regulatory goal 'Austria is not an immigration country' into the federal constitutional law of 1920 (1929 version).

Moreover, the petition called for a quasi-segregation of native German-speaking children in schools from foreign children (paras 6 and 7) and for the end of 'premature conferment of citizenship' (para 9). Since then, the slogan 'Austria First' has continued to be used throughout FPÖ campaigns (metonymically implying that Austria and the Austrians have to be given priority to other countries and non-Austrians), thus defining the 'real Austrian' as white and 
Christian (topos of definition). The central proposal of the 'Austria First' focussed on the proposition that 'Austria is not an immigration country' (Österreich ist kein Einwanderungsland) used widely to date in FPÖ and BZÖ campaigns and which is most certainly fallacious.

In 2002, a combined revision of the Foreigners Act (Fremdengesetz), the Foreign Labour Act (Ausländerbeschäftigungsgesetz) and the Asylum Act (Asylgesetz-AsylG) was passed at the initiative of the right-wing ÖVP-FPÖ government. Referred to as the 'Integration Agreement' (Integrationsvereinbarung), its official purpose was to 'build a bridge between all the people living in Austria - both Austrian and non-Austrian citizens - in order to guarantee a peaceful coexistence'; that is, to make it easy for migrants to become socio-culturally and linguistically integrated, i.e. assimilated (topos of culture). This law stipulates that, within the first four years of residence in Austria, 100 45-minute instructional units of a German language course are compulsory for most immigrants (with clearly noted exceptions for privileged migrants such as foreign correspondents, UN officials and so forth). If migrants do not take language classes within the first two years of their stay in Austria, they risk a fine of $€ 100-200$. If they have not completed the language course after four years, they can be refused a settlement and residence permit. We quote the first paragraph here:

The Integration Agreement serves the integration of legally justified or long-term citizens of other countries. It serves the acquisition of German language skills, specifically reading and writing skills, to be able to participate in the social, economic, and cultural life in Austria. ${ }^{18}$

In this way, the Integration Agreement recontextualises the rhetoric of the 'Austria First' petition, and pre-empts by some five years the requirements proposed by Gordon Brown on 10 September 2007. The Integration Agreement was widely criticised by experts (Krumm, 2002): the 100 sessions of language instruction were judged insufficient to acquire the necessary competence in German, the compulsory dimension of the 'obligatory' language acquisition was then unique in the EU context, and the name 'Integration Agreement' carries cynical connotations since there is neither 'agreement' (with whom and by whom?) nor provision for 'integration'. German language is thus regarded as another salient criterion (apart from being white, born to Austrian parents and Christian) for being defined as 'a real Austrian'.

\section{Returning to contemporary discourse}

At this point, we can return to the examples introduced at the start of this article. Inside the BNP 'British Jobs' leaflet (Figure 5), the party present their policies in a now standard '10-point plan' (see Richardson, 2008, for a variation on their election pledges).

The BNP have repeatedly argued that racism and antisemitism play no part in their policies, and that political extremism is a thing of the past. If this were the case, their 10-point programme could be judged as within the mainstream of (nationalist, authoritarian, populist) British politics. However, the BNP's own Guide to Language Discipline (British National Party, 2005) reveals their continued dedication to biological racism. This document was written for internal consumption and intended to instruct party members and activists in how to 'stick to the party's true message and convey it to the voting public in a clear and consistent way' (British National Party, 2005, p. 1). The following rules are important, given the contents of the BNP 'British Jobs' leaflet:

Rule \#15. BNP activists and writers should never refer to 'black Britons' or 'Asian Britons' etc, for the simple reason that such persons do not exist. These people are 'black residents' of the UK etc, and are no more British than an Englishman living in Hong Kong is Chinese. Collectively, foreign residents of other races should be referred to as 'racial foreigners', a non-pejorative term that makes clear the distinction needing to be drawn. [...]

Rule \#17. Britain does not have 'immigrants,' a term proper for use in settler societies like Canada, 


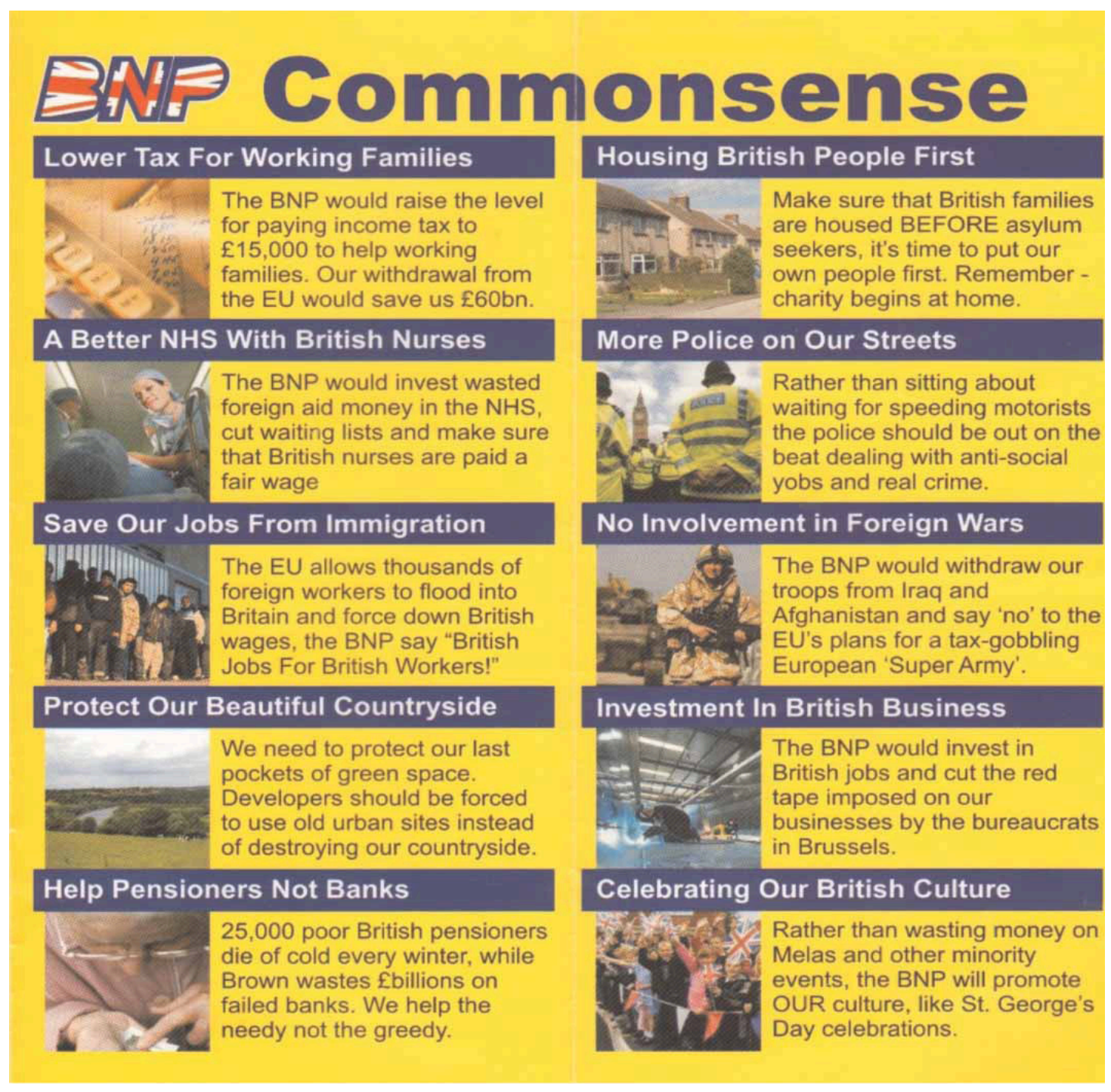

Figure 5. BNP 'Commonsense'.

Argentina, and the USA. It has 'guest workers,' 'foreign workers,' or 'descendants of foreign workers'. They are, depending on who they are, 'racial foreigners,' 'religious foreigners' or 'persons of foreign religion,' or 'ethnic foreigners'. The last term is meant to apply to persons racially similar to Britons, but ethnically dissimilar, like Dutchmen. (British National Party, 2005, p. 3)

Thus, despite their protestation and self-construction as a 'modern democratic party', the BNP replicates and recontextualises exactly the key ideological commitment of British fascist and far-right discourse discussed above: non-white (non-Christian) Britons 'do not exist'. The only British people are white, and so when the nominals 'British' or 'Briton' are used, this should axiomatically be taken to exclude these variously defined 'racial foreigners', 'religious foreigners', 'persons of foreign religion' or 'ethnic foreigners'. With the benefit of this contextualisation and elucidation, the repeated use of 'British' in Figure 5, above, hardly needs further analysis: the BNP would ensure that '[white] Nurses are paid a fair wage'; they are concerned about '[white] wages' and 'would invest in [white] jobs'; they are concerned to help 'poor [white] pensioners'; and they make sure '[white] families are housed first'.

The BNP's use of the cliché 'charity begins at home' is redolent of the Heimat rhetoric of Austrian right-wing and the topos of the 'real Austrian' and the slogan 'Austria First' (see above). The election poster of the FPÖ in Figure 6 not only uses the Austrian Eagle with 


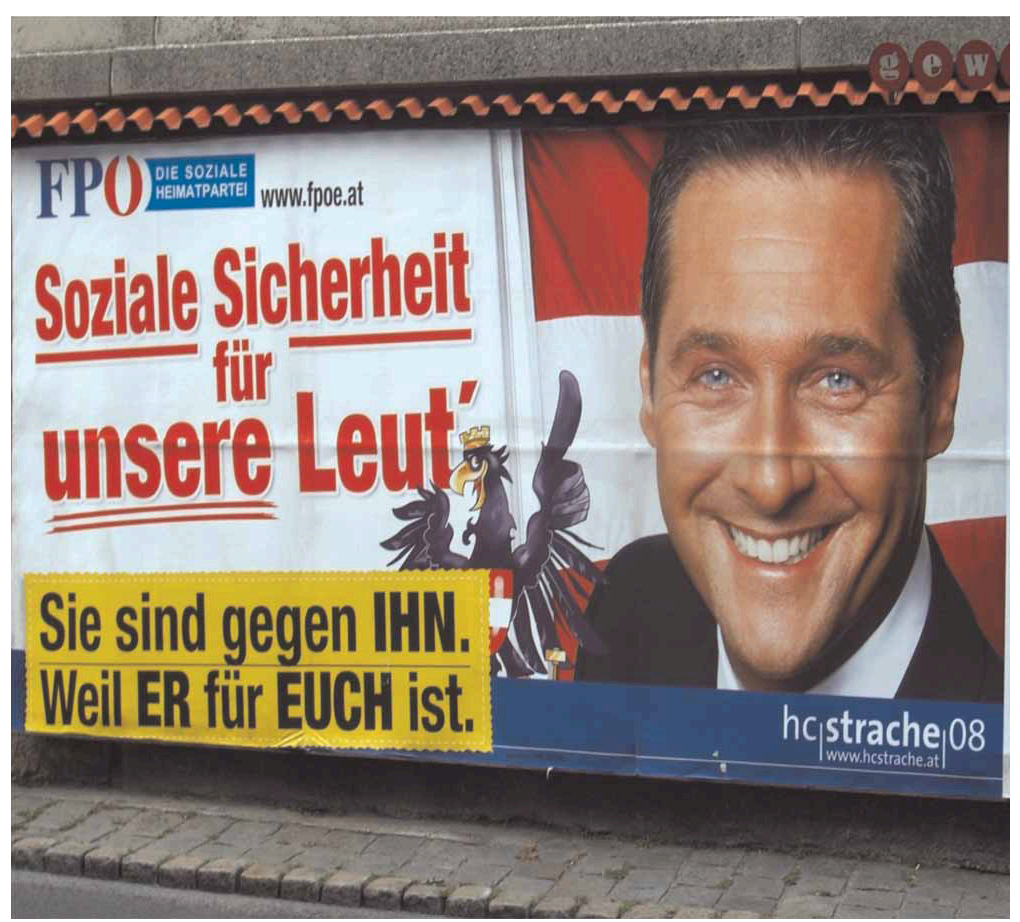

Figure 6. 'Unsere Leut', FPÖ, Vienna, 2008.

a 'thumbs up' sign for HC Strache, but - even more importantly - employs exclusionary rhetoric via Manichean division and promises 'Social Security for our people' ('Soziale Sicherheit für Unsere Leut'). The explicit definition of who is actually meant remains vague apart from the many symbols which point to the 'Austrians' and their 'Heimat' such as the use of the Austrian flag, the Austrian Eagle and the predication of the FPÖ as the 'Soziale Heimatpartei' ('the social homeland party'). Below, we encounter more vague rhetoric: 'Sie sind gegen Ihn weil Er für Euch ist!' ('They are against him because he is for you!') The vague pronouns seem to suffice to indicate that people know who the anonymous enemies are. Moreover, this slogan implies that 'vague enemies' oppose HC Strache because he is for 'you'. Via implicature, this slogan further suggests that, if these enemies oppose Strache, then they also oppose 'you' and endanger people's (your) social security. In this way, HC Strache discursively constructs himself as the rescuer of 'us' (real Austrians) from vague and dangerous 'others'. The use of the term 'Leut' in this context is another indicator for the claim that real Viennese are constructed as 'Us' because 'Leut' is Viennese colloquial usage of the more standard version 'Leute'.

The BZÖ's current use of the term 'Lebensraum' in its recent Party programme, quoted above, fits into the overall ideology which is manifested in the discourse about jobs and employment. Schmitz-Berning (2007, pp. 375-380) suggests that at least three meanings of Lebensraum currently exist: firstly, related to environmental issues; secondly, related to personal space, frequently employed in advertisements; and thirdly as apparent in Hitler's speeches and in Mein Kampf which drew on previous publications from the nineteenth century like Politische Geographie oder die Geographie der Staaten, des Verkehrs, und des Krieges (1897 by Friedrich Ratzel). In short, the semantic history of this term inevitably entails the legitimation of racist ideology to expand the German Reich to the East through violent means (Schmitz-Bering, 2007 , p. 375). In the BZÖ's programme, the term is embedded in a paragraph about the healthy environment, thus alluding to both the first and the third meanings. The Lebensraum ideology focussed right from the beginning on farmers as the backbone of a 'new Germany' (in contrast to an 'un-rooted' population which contextually infers to 'Jews'). ${ }^{19}$ In this way, 
the strategy of 'calculated ambivalence' is employed which means that several readings are possible: BZÖ politicians will certainly claim that the negatively loaded reading was never intended, while, on the other hand, party members might deconstruct the text according to the meaning related to NS-ideology (Engel \& Wodak, 2009).

\section{Conclusions}

To be clear, we are not arguing that mainstream British politicians like Brown really mean 'jobs for whites' when they argue for 'British jobs for British workers'. Neither do Austrian mainstream parties endorse only white and Christian 'real Austrians' or imply that Austria is a 'non-immigration country'. However, their economic exclusionary politics opens the door to the more pernicious, biologically based, racism of the far right. These parties are able to repeat the same phrase - given legitimacy by mainstream democratic politicians - but mean something radically different. Their 'British worker' is white, and only white, with 'racial foreigners' only here on sufferance, to be repatriated at the earliest convenience. Similarly, the 'real Austrian' is conceived as being Christian and white. Our historical deconstruction of loaded terms and slogans via the discourse-historical approach combined with semantic history illustrates that in both investigated countries, the nativist job rhetoric stems from antisemitic, nationalistic, and fascist ideologies from the nineteenth and twentieth centuries, although implemented in significantly different ways due to colonialism, on the one hand, and National Socialism, on the other. Such an approach also allows decoding vague pronouns in their multiple readings as presented in Figure 6. Of course, due to space restrictions, we can only provide snapshots of an extremely complex historical development in both countries. However, the recontextualisation and redefinition of clearly ideologically loaded concepts in electoral contexts in specific political genres, such as party programmes and election posters, provides ample evidence of subtle historical continuities via visual tropes, pragmatic presuppositions and implicatures, and argumentative topoi. Complementing a conceptual history with the more detailed context analysis and the analysis of single loaded terms in their textual and visual co-texts and broader contexts as proposed by the DHA allows the tracing of the recontextualisation of racist and exclusionary rhetoric in manifold and systematic ways.

In any case, the current right-wing populist discursive strategy of addressing multiple audiences via 'calculated ambivalence' - or, in the BNP's terms, an 'image of moderate reasonableness' - proves effective and indicates that collective memories transport historical meanings which can be instrumentalised in politically dangerous ways.

\section{Acknowledgements}

We thank Bernhard Forchtner, Katharina Köhler, Michał Krzyżanowski and Martin Reisigl for their valuable comments.

\section{Notes on contributors}

John E. Richardson is a senior lecturer in the Department of Social Sciences, Loughborough University. He is co-editor of the online journal Studies in Language and Capitalism, and on the editorial board of the journals Discourse and Society, Social Semiotics and the Journal of Language and Politics. His research interests include structured social inequalities, British fascism, racism in journalism, (critical) discourse analysis and argumentation. His recent publications include the book Analysing newspapers: An approach from critical discourse analysis (Palgrave, 2007), special issues of the journals Journalism Studies, Social Semiotics and Critical Discourse Studies, and articles on the discourse analysis of newspapers, readers' letters and party political leaflets. 
Ruth Wodak is Distinguished Professor of Discourse Studies at Lancaster University (and affiliated to the University of Vienna). Besides various other prizes, she was awarded the Wittgenstein Prize for Elite Researchers in 1996. Her research interests focus on (critical) discourse studies; gender studies; language and/in politics; identity politics; prejudice, racism, and discrimination; and on ethnographic methods of linguistic field work. She is member of the editorial board of a range of linguistic journals and co-editor of the journals Discourse and Society, Critical Discourse Studies and Language and Politics, and of the book series Discourse Approaches to Politics, Society and Culture (DAPSAC). Recent book publications include The discourse of politics in action - politics as usual (2009); Ist Österreich ein 'deutsches' Land? (with R. de Cillia, 2006); Migration, identity and belonging (with G. Delanty, P. Jones, 2008); and The discursive construction of history. Remembering the Wehrmacht's war of annihilation (with H. Heer, W. Manoschek, A. Pollak, 2008). For more information on on-going research projects and recent publications see http://www.ling.lancs.ac.uk/profiles/265.

\section{Notes}

1. Toby Helm (2007), 'Gordon Brown pledges jobs for British workers, Daily Telegraph', available at http:// www.telegraph.co.uk/news/uknews/1562791/Gordon-Brown-pledges-jobs-for-British-workers.html (consulted 12 May 2009).

2. Gordon Brown's full speech to the TUC available at: http://www.telegraph.co.uk/news/uknews/ 1562685/Gordon-Browns-speech-to-the-TUC-in-full.html (consulted 12 May 2009).

3. Quoted in Anne Perkins (2002), 'New Labour gurus warn Blair to get tough on immigration', Guardian, available at http://www.guardian.co.uk/politics/2002/sep/13/immigration.immigrationand publicservices (consulted 12 May 2009).

4. BNP Constitution (9th edn) is available at: http://bnp.org.uk/resources/constitution-9th-edition/ (consulted 12 May 2009).

5. Quoted in http://bnp.org.uk/2007/12/welcome-to-the-age-of-treason/?akst_action=share-this; see also http://bnp.org.uk/2007/12/labour-lie-nailed-british-jobs-are-for-foreign-workers/ (both consulted 12 May 2009).

6. See Krzyżanowski and Wodak (2008) for an extensive summary for the history of the FPÖ.

7. 'Arbeit ist Heimat. Wir wollen die Regierenden nachhaltig daran erinnern, dass es eine Grundaufgabe des Sozialstaates ist, dem Staatsvolk - also der gewachsenen, einheimischen Bevölkerung - genug Arbeitsplätze zu adäquater Entlohnung zu bieten, um österreichischen Familien einen angemessenen Lebensstandard und soziale Sicherheit zu ermöglichen' (http://www.faoe.at/; consulted May 26 2009).

8. The orange position on the theme of 'Lebensraum'

Only a healthy environment is liveable [...]. We are against the agrarian lobby of the European Union as well as against their endorsement of genetics [...] This secures the survival of our farmers and supports the production of healthy food-products.

Orange Goals and Responses

[...] Renationalisation of agrarian industry; Securing of jobs on the farm

Available at http://www.bzoe.at/index.php?content=bzoe_programm (consulted 29 May 2009).

9. Within argumentation theory, 'topoi' can be described as parts of argumentation which belong to the required premises. They are the formal or content-related warrants or 'conclusion rules' which connect the argument(s) with the conclusion, the claim (for more details, see Reisigl \& Wodak, 2001, pp. 69-80).

10. The topos of the 'real Austrian' first appeared in post-war Austria in the national election campaign 1969 by the ÖVP against the then Social-Democratic Jewish Austrian chancellor Bruno Kreisky (see Wodak et al., 1990); the FPÖ then recontextualised this antisemitic topos and employed it for all 'Others'.

11. Blatchford, a self-described non-Marxist socialist, is often cited by far-right theorists to demonstrate how far the Labour movement has fallen in its support of the (white) working class. In fact, his views are more accurately described as economic nationalist (see Blatchford, 1893); he is held in high regard by the contemporary British far-right as a standard bearer for English sovereignty and racial heredity (Reynolds, n.d.). 
12. http://de.wikipedia.org/w/index.php?title=Datei:Antisemitisches_Wahlplakat_CSP_1920.jpg\&file timestamp=20090120233426; Wahlplakat der Christlichsozialen Partei in Wien) from the Christian-Socialist Party, 1920, is to be found at Wiener Stadt- und Landesbibliothek, Plakatsammlung: P 306 (see also Geser, \& Loacker, 2000, Abb. 114).

13. www.eppinger.at/Eppinger/Standpunkte/Eintr\%C3\%A4ge/2009/3/6_Die_Araber_lieben_die_Pal\% C3\%A4stinenser_nicht_files/boykott.jpg (consulted 5 June, 2009). We also find many instances of antisemitic nativist rhetoric in Austria's First Republic, inter alia from the Christian-Social Party, the forerunner of the ÖVP: for example, election posters with 'Rettet Österreich' (Rescue Austria) 1920 which depict Jews as dangerous snakes strangulating the Austrian Eagle in the Austrian coat of arms.

14. The first FPÖ chairman, Anton Reintaller, had been 'a member of the National Steering Committee of the Austrian NSDAP and the SS-Brigadenführer who held the position of Minister of Agriculture in the Austrian government of Seyß-Inquart in 1938' (ibid.). Reintaller's Nazi past, as well as that of other key members of the FPÖ at the time of its founding (such as Lothar Rendulic or the later FPÖ chairman Friedrich Peter), made the FPÖ the 'successor to the Austrian NSDAP' (Manoschek, 2002, p. 7) and shaped it in a way that precluded any treatment of the party 'as a normal third party like the German Liberals (FDP) or other small liberal parties in West European Countries' (ibid.) (see Krzyżanowski \& Wodak, 2008 for further details).

15. See Krzyżanowski and Wodak (2008).

16. See http://library.fes.de/fulltext/asfo/01014002.htm for more details. The programme proposes similar issues as does the 'Austria First Petition'. We are indebted to Martin Reisigl for this information. The DVUis an extremist right-wing party which was concerned with the 'homogeneity' of Germany and its position in the EU. Moreover, slogans such as 'Österreich über alles, wenn es nur will' (Austria above all, if it only wants) were employed since 1848, coined by Hörningh, to distinguish oneself from Germany, and recontextualised in the Austro-fascist era after 1934.

17. In this way, the 'HC Strache Rap Österreich Zuerst' became salient in election campaign for European Parliament, June 2009; http://www.youtube.com/watch?v=pVnzYs4HYBQ (consulted 8 June 2009).

18. '14. (1) Die Integrationsvereinbarung dient der Integration rechtmäßig auf Dauer oder längerfristig niedergelassener Drittstaatsangehöriger. Sie bezweckt den Erwerb von Kenntnissen der deutschen Sprache, insbesondere der Fähigkeit des Lesens und Schreibens, zur Erlangung der Befähigung zur Teilnahme am gesellschaftlichen, wirtschaftlichen und kulturellen Leben in Österreich.' http:// www.integrationsfonds.at/fileadmin/Integrationsfond/3_integrationsvereinbarung/downloads/nag_ iv.pdf.

19. See Himmler (1944) with extensive passages on the salience of German farmers.

\section{References}

Bauböck, R. (2003). Österreichische Migrationspolitik. Vienna: ICMPD, (www.migration.cc).

Billig, M. (1978). Fascists: A social psychological view of the National Front. London: Harcourt Brace Jovanovitch.

Blatchford, R. (1893). Merrie England. Clarion Office, Walter Scott LTD.

British National Party (2005). BNP language \& concepts discipline manual. BNP Policy Research.

Brown, G. (2007). Why the BNP is still fascist. What Next? No. 31. Retrieved May 6, 2008 from http:// www.whatn6extjournal.co.uk/Pages/Latest/Current.html

Chilton, P. (2004). Analysing political discourse: Theory and practice. London: Routledge.

Cohen, S. (2006a). Standing on the shoulders of fascism: From immigration control to the strong state. Stoke: Trentham.

Cohen, S. (2006b). Deportation is freedom! The Orwellian world of immigration controls. London: Jessica Kingsley.

Eatwell, R. (1991). The Holocaust Denial: a study in propaganda technique. In L. Cheles, R. Ferguson, \& M. Vaughan (Eds.), Neo-fascism in Europe (pp. 120-146). London: Longman.

Engel, J., \& Wodak, R. (2009). Kalkulierte Ambivalenz: Störungen’ und das Gedankenjahr': Die Causen Siegfried Kampl und John Gudenus. In R. de Cillia \& R. Wodak (Eds.), Gedenken im Gedankenjahr (pp. 79-100). Innsbruck: Studienverlag.

Gärtner, R. (2002). The FPÖ, foreigners and racism in the Haider era. In R. Wodak \& A. Pelinka (Eds.), The Haider Phenomenon in Austria (pp. 17-33). New Brunswick, NJ: Transaction.

Geser, G., \& Loacker, A. (Eds.). (2000). Die Stadt ohne Juden. Vienna: Filmarchiv Austria.

Himmler, H. (1944). Amerikanismus - Eine Weltgefahr. Munich. 
John, P., Margetts, H., Rowland, D., \& Weir, P. (2006). The BNP: the roots of its appeal. London: Joseph Rowntree Charitable Trust.

Koselleck, R. (1992). Vergangene Zukunft. Frankfurt: Suhrkamp.

Krumm, H.-J. (2002). 'One Sprachen konten wir uns nicht ferstandigen. Ferstendigung ist wichtig': Entwicklung und Tendenzen in der Sprachlehrforschung im Bereich der Migration und Integration. Deutsch als Zweitsprache, 2, 32-41.

Krzyżanowski, M., \& Wodak, R. (2008). The politics of exclusion. Debating migration in Austria. New Brunswick, NJ: Transaction.

Lunn, K. (1989). The ideology and impact of the British Fascists in the 1920s. In T. Kushner \& K. Lunn (Eds.), Traditions of intolerance: Historical perspectives on fascism and race discourse in Britain (pp. 140-154). Manchester: Manchester University Press.

Manoschek, W. (2002). FPO, OVP and Austria's Nazi past. In R. Wodak \& A. Pelinka (Eds.), The Haider phenomenon in Austria (pp. 3-16). New Brunswick, NJ: Transaction.

Matouschek, B., Wodak, R., \& Januschek, F. (1995). Notwendige Maßnahmen gegen Fremde? Genese und Formen von rassistischen Diskursen der Differenz. Vienna: Passagen Verlag.

Pelinka, A., \& Wodak, R. (Eds.). (2002). Dreck am Stecken. Vienna: Czernin Verlag.

Reisigl, M., \& Wodak, R. (2000). 'Austria First'. A discourse-historical analysis of the Austrian 'AntiForeigner-Petition' in 1992 and 1993. In M. Reisigl \& R. Wodak (Eds.), The semiotics of racism. Approaches in critical discourse analysis (pp. 269-303). Vienna: Passagen Verlag.

Reisigl, M., \& Wodak, R. (2001). Discourse and discrimination. Rhetorics of racism and antisemitism. London: Routledge.

Reisigl, M., \& Wodak, R. (2009). The discourse-historical approach. In R. Wodak \& M. Meyer (Eds.), Methods of CDA (pp. 87-121). London: Sage.

Reynolds, D. (n.d.). Blatchford: The pioneer English socialist, Freedom Party. Retrieved May 15, 2009 from http://www.freedompartyuk.net/public/standardbearers/blatch.html

Richardson, J.E. (2008). 'Our England': discourses of 'race' and class in party election leaflets. Social Semiotics, 18(3), 321-336.

Richardson, J.E., \& Wodak, R. (in press). The impact of visual racism: Visual arguments in political leaflets of Austrian and British far-right parties. Controversia.

Schiedel, H., \& Neugebauer, W. (2002). Jörg Haider, die FPÖ und der Anitsemitismus. In R. Wodak \& A. Pelinka (Eds.), The Haider phenomenon in Austria (pp. 11-32). New Brunswick, NJ: Transaction.

Schmitz-Berning, C. (2007). Vokabular des Nationalsozialismus, 2nd revised edn. Berlin: de Gruyter.

Schuster, L., \& Solomos, J. (2004). Race, immigration and asylum: New Labour's agenda and its consequences. Ethnicities, 4(2), 267-287.

Silberner, E. (1952). British socialism and the Jews. Historia Judaica, XIV, $27-52$.

Tyndall, J. (1977). Beyond capitalism and socialism: Industrial policy for the modern age. National Front Policy Committee.

Wodak, R. (2001). The discourse-historical approach. In R. Wodak \& M. Meyer (Eds.), Methods of critical discourse analysis (pp. 63-95). London: Sage.

Wodak, R. (2003). Populist discourses: The rhetoric of exclusion in written genres. Document Design, 4(2), $132-148$.

Wodak, R. (2008). 'Us' and 'Them': Inclusion/exclusion - discrimination via discourse. In G. Delanty, P. Jones, \& R. Wodak (Eds.), Migration, identity, and belonging (pp. 54-78). Liverpool: Liverpool University Press.

Wodak, R., \& Meyer, M. (2009). Critical discourse analysis: History, agenda, theory and methodology. In R. Wodak \& M. Meyer (Eds.), Methods of CDA (pp. 1-33). London: Sage.

Wodak, R, \& van Dijk, T.A. (Eds.). (2000). Racism at the top: Parliamentary discourses on ethnic issues in six European states. Klagenfurt: Drava.

Wodak, R., Nowak, P., Pelikan, J., Gruber, H., de Cillia, R., \& Mitten, R. (1990). 'Wir sind alle unschuldige Täter'. Diskurshistorische Studien zum Nachkriegsantisemitismus. Frankfurt: Suhrkamp. 